\title{
Opportunity for aggression as a reinforcer in mice
}

AUKE TELLEGEN, JOSEPH M. HORN, and ROSS G. LEGRAND, ${ }^{I}$ University of Minnesota, Minneapolis, Minn. 55455

Male mice acquired, extinguished, and reversed a position response in a T-maze when the opportunity to attack a "victim" mouse was provided as reinforcer. Half of the Ss were also given a fight before each maze trial. These Ss, compared to $S$ s run without prefights, were superior in choice performance early during acquisition and reversal learning, and showed slower extinction. It was also found that preference for the aggression-rewarded side of the maze increased from first to second trials given on the same day.

Very few studies of aggressive behavior have been concerned with the possible role of aggression, particularly intraspecific aggression, as a reinforcer of instrumental behavior. For example, while intraspecific aggression in the house mouse has been well documented and has been studied extensively (cf. Scott, 1958, 1966), no mouse studies have been reported, to the present authors' knowledge, demonstrating reinforcement by aggression. Lagerspetz (1964) has suggested that aggressively aroused mice will exhibit a clear preference for aggressive behavior, but that without such arousal the preference will only be slight. Lagerspetz based her conclusions on latency data obtained in what essentially was a simple runway situation. Consequently, her findings did not demonstrate that mice placed in a choice situation will in fact prefer the alternative leading to aggression, or that prior aggressive arousal is a necessary condition for such a preference. The present study was designed to deal more directly with these questions. Male mice trained to be reliable fighters were run in a modified $\mathrm{T}$-maze in which a correct position choice was followed by an opportunity to fight. The maze procedure consisted for all Ss of three stages: acquisition, extinction, and reversal. One half of the Ss (the "prefight group") were given a brief fight immediately preceding each choice, and their performance was compared with that of the other half, a control group run without prefights.

\section{METHOD}

Subjects were 16 male $\mathrm{Balb} / \mathrm{cJ}$ mice obtained from the Jackson Laboratory at the age of approximately 30 days, and housed individually upon arrival. At age 100 days Ss began a 12-day period of training as fighters. Training took place in a $15 \times 6 \times 8 \mathrm{in}$. wooden, black painted box, divided in the middle by a removable sliding partition. The "victims" used in training and later in the maze were $\mathrm{C} 57 / 6 \mathrm{~J}$ mice, also obtained from Jackson Laboratory. Mice of this strain had been found to be suitable standard victims since they rarely fought vigorously when attached. On the first two days of the 12-day period each $S$ and a victim were placed once in the box on opposite sides of the partition. The partition was then removed, and the two mice were detained in the box for $2 \mathrm{~min}$, or for $5 \mathrm{sec}$ after fighting had begun, whichever happened first, upon which $\mathrm{S}$ was returned to its home cage. On the following 10 days actual training to fight took place. An adaptation of the "dangling" procedure described by Scott (1958) was used: $S$ was placed in the training box (with partition removed) and a victim was held suspended by its tail in front of $S$. If no fight was initiated within a few seconds, the victim was dangled so as to touch $S$ lightly until $S$ attacked the victim or otherwise until $2 \mathrm{~min}$ had elapsed. This episode was repeated two more times, with $15 \mathrm{sec}$ of rest between episodes. The three episodes constituted one training session, and two sessions, separated by approximately $30 \mathrm{~min}$, were held each day. On the last training day each $\mathrm{S}$ was in addition given 2 min of free exploration in the T-maze.

The wooden T-maze had a black $8 \times 6 \times 6$ in. start box and an $11 \times 6 \times 6$ in. stem. The stem was directly connected with two $12 \times 6 \times 6$ in. goal boxes, the long axes of which were perpendicular to the long axis of the stem. A permanent wooden partition along the long axis of the stem divided the latter in two $23 / 4-$ in. wide alleys. This partition continued backward so as to separate the two goal boxes, and ended $1 \frac{1}{2}$ in. in front of the start box so that $S$ could enter either alley upon leaving the start box. The left alley of the stem was painted grey and led to the grey painted left goal box. The right alley, painted in vertical black and white stripes, led to the identically painted right goal box. There were metal guillotine doors at the end of both alleys (at the entrance of each goal box) and between start box and stem. Each goal box also had a removable sliding metal partition painted in the same way as the goal box. Both partitions were parallel to, and 8 in. away from the common wall separating the goal boxes. The two goal boxes were thus divided into a larger $(8 \times 6$ in.) and a smaller $(4 \times 6$ in.) compartment, the smaller one being farthest from the alley. The entire maze was covered by hinged sections of framed wire screen.

The maze-running procedure for the eight prefight Ss was as follows: During acquisition Ss were given two trials each day for 18 days, where each trial is defined as one free choice followed by one forced choice to the side opposite to that of the preceding free choice. Before each of the four daily choices the partitions were inserted in the goal boxes, a victim was placed in both small goal box compartments, the two goal box doors were raised, and the start box door was closed (the presence of a victim in both goal boxes eliminated differential victim-emitted cues that might direct S's choice). Upon placing $S$ in the start box $E$ would dangle a victim in front of $S$. $S$ would typically attack promptly, and after approximately $5 \mathrm{sec}$ of aggressive contact the victim was removed. The cover of the start box was then closed, and the start box door raised. When the choice was free $S$ was allowed to move about in the start box and alleys until it had placed all four feet inside one of the goal boxes. The goal box door was then lowered to prevent retracing. On forced choices, a clear plastic partition was inserted preventing access to the alley leading to the previously chosen side of the maze. Choice latency, i.e., the time elapsed between raising the start box door and S's entering the goal box, was recorded for each choice, using a stopwatch.

When on a free or forced choice, $S$ entered the correct goal box-left for half of the Ss, right for the other half of the Ss-the partition separating $S$ from the victim was removed, providing $S$ with an opportunity to fight. After approximately $10 \mathrm{sec}$ of aggressive contact the victim was taken from the goal box after which $S$ was removed and returned to its home cage. When $S$ entered the incorrect goal box the victim was removed first, next the partition, and $S$ was then detained in the empty goal box for $15 \mathrm{sec}$, without a fight, before being returned to its home cage. Ss were run in squads of four; the interval between choices of the same $S$ was approximately $4 \mathrm{~min}$.

Acquisition was followed by 14 days of extinction. The procedure was the same as during acquisition with the following changes: The four daily choices were all free, and all choices were treated as incorrect. Extinction was followed by an 18-day reversal period identical to the acquisition period, except that for each $\mathrm{S}$ the correct and incorrect sides of the maze were reversed.

The procedure for the eight Control Ss was identical to the 


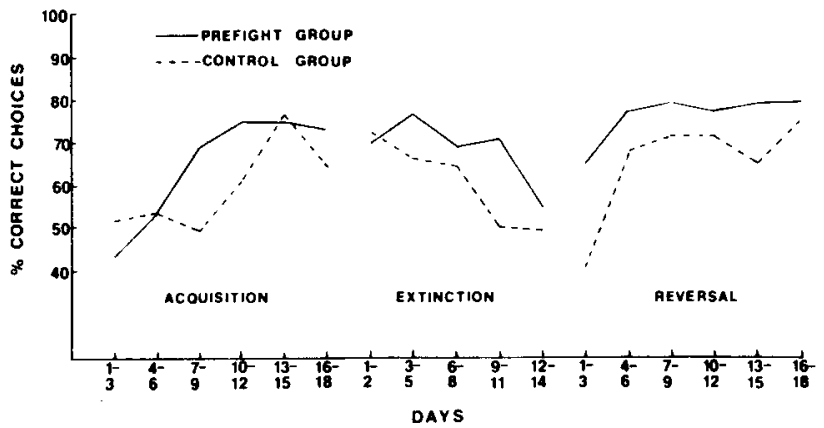

Fig. 1. Mean percentages of correct choices in the Control and Prefight groups on successive blocks of days.

one followed with the Prefight Ss, except that Control Ss were given no prefight in the start box and instead were detained for a 7-sec period before the start box door was raised.

\section{RESULTS}

Choice data and latencies were subjected to factorial analyses of variance, performed on successive blocks of six days, followed up by individual tests. Analyses of the free choices incorporated three factors: Prefight (absent vs present), Side of Reinforcement (left vs right), and Trials (Trial 1 vs Trial 2). Analyses of the latencies were based on all four latencies recorded each day and included a fourth factor, Reinforcement, allowing for a comparison of latencies of reinforced and nonreinforced choices.

The choice data plotted in Fig. 1 show that both the Control group and the Prefight group acquired a preference for the aggression-rewarded side of the maze, both during acquisition and reversal. The average percentages of correct choices during the last six days of acquisition were $71 \%$ and $74 \%$ for the Control and Prefight $\mathrm{Ss}$, respectively. The percentages are significantly above chance level $(p<.05$, Controls; $\mathrm{p}<.05$, Prefight group; $\mathrm{p}<.005$, the two groups combined). The corresponding percentages during the last six days of the reversal period were $71 \%$ and $79 \%(\mathrm{p}<.02$, Controls; $p<.01$, Prefight group; $p<.0005$, the two groups combined). The latency data also showed a significant reinforcement effect, the latencies of correct choices being clearly shorter than those of incorrect choices $(\mathrm{p}<.005$, Days 13-18, acquisition; $p<.0005$, Days 13-18, reversal).

A comparison of the Prefight group with the Controls indicated that the choice performance of the former tended to be superior, as shown in Fig. 1. The difference between the two groups was found to be significant early in acquisition (Days $7-12, p<.05$ ), late in extinction (Days 9-14, p<.05), and again early in reversal (Days $1-6, p<.05$ ). The latency data showed no significant differences between the two groups.

A final set of results revealed unexpectedly a daily recurring facilitation effect: The choice data showed an increase in the percentage of correct choices on the second free trial as compared to the first free trial. During acquisition the percentage of correct free choices (computed for the total sample) increased from $58 \%$ on Trial 1 to $70 \%$ on Trial 2 on Days $7-12(\mathrm{p}<.005)$, and from $69 \%$ to $76 \%$ on Days $13-18$ [not significant $(\mathrm{p}<.25)$ although in the same direction]. The latency data for these same periods revealed a corresponding, significant Trial by Reinforcement interaction resulting from the fact that the difference in latency between correct and incorrect choices, already noted above, was larger on the last two choices than on the first two choices $(\mathrm{p}<.005$, Days $7-12 ; p<.02$, Days $13-18$ ). The same patterns of choices and latencies were obtained during reversal learning, and the $p$ values of all four corresponding significance tests were below .005 .

The results clearly show that the opportunity to fight functioned as a reinforcer in the present experiment. Furthermore, extinction as well as reversal of the location of the reinforcer produced effects comparable to those observed with other reinforcers such as food and water.

Both the effects of the prefight manipulation and the trial effect indicate that the preference for aggression will be more clearly evident when $\mathrm{S}$ has undergone a prior "warm-up" experience. In fact, on trials preceded by neither an earlier trial nor a prefight (in other words, on first trials in the Control group), preference for the aggression-rewarded side of the maze is rather slight: $67 \%$ and $55 \%$ on Days $13-18$ of acquisition and reversal, respectively (neither value differs significantly from $50 \%$ ). On the other hand, on trials preceded by both an earlier trial and a prefight (that is, on second trials in the Prefight group), preference for the aggression-rewarded side of the maze is clear cut: $77 \%$ and $96 \%$, respectively, on Days 13-18 of acquisition and reversal. The warm-up effects may be due to the fact that just prior to their occurrence Ss had been engaged in aggressive behavior (in the goal box following the first correct choice, and in the start box if $S$ was in the Prefight condition). In that case the results would be consistent with Lagerspetz's notion that $S$ will show a clear preference for aggression only when aroused by prior aggression. The data, however, are not decisive on this point. It is possible that factors other than aggression contributed to the observed facilitation. For example, merely negotiating the maze might facilitate performance on the next trial, and thus contribute to the observed trial effect. Whatever the nature and number of mechanisms mediating warm-up phenomena, their occurrence suggests the importance of exogenous factors for the activation of a preference for aggression. The present results thus do not conform to a strictly endogenous view of aggresssive motivation.

\section{REFERENCES}

LAGERSPETZ, K. Studies on the aggressive behaviour of mice. Helsinki: Suomalainen Tiedeakatemia, 1964

SCOTT, J. P. Aggression. Chicago: University of Chicago Press, 1958.

SCOTT, J. P. Agonistic behavior of mice and rats: A review. American Zoologist, 1966, 6, 683-701.

1. Presently at St. Olaf College, North

\section{(Continued from page 103)}

dosages fail to produce greater change. This finding suggests that whatever CNS changes are produced by magnesium pemoline are "triggered" by the drug, and function in an all-or-none fashion. This is, admittedly, a speculative hypothesis, and further research of a parametric nature will be required to verify or refute it.

\section{REFERENCES}

BEACH, G., \& KIMBLE, D. P. Activity and responsivity in rats after magnesium pemoline injections. Science, 1967, 155, 698-701.
GLASKY, A. J., \& SIMON, L. N. Magnesium pemoline: Enhancement of brain RNA polymerases. Science, 1966, 151, 702-703.

PLOTNIKOFF, N. Magnesium pemoline: Enhancement of learning and memory of a conditioned avoidance response. Science, 1966, 151, 703-704.

\section{NOTES}

1. The authors wish to express appreciation to Abbott Laboratories for supplying the magnesium pemoline used in the present study.

2. Present address: Department of Psychology, University of Kentucky, Lexington, Ky. 40506. 